\title{
A CSR KÜLÖNLEGES BÁNÁSMÓDJA
}

\section{Szerző:}

Bene Ágnes

Debreceni Egyetem

Első szerző e-mail címe: agibenehr@yahoo.com

\section{Lektorok:}

Bocsi Veronika

Debreceni Egyetem

Kozák Anita

Eszterházy Károly Főiskola

Nemes Magdolna

Debreceni Egyetem

Mező Ferenc

Debreceni Egyetem

Bene Á. (2016): A CSR különleges bánásmódja. Különleges Bánásmód, II. évf., 2016/1. szám, 27-41. DOI 10.18458/KB.2016.1.27

\begin{abstract}
Absztrakt
A vállalati társadalmi felelösségvállalás (CSR, Corporate Social Resposibility) lényege egy kiterjesztett definíció szerint, hogy „a vállalatnak is jó legyen és a szóban forgó társadalmi célt is szolgáljuk" (Kotler és Lee 2007. 10. o.). Kotler logikáját követve jelen tanulmány célja a vállalatok társadalmi felelösségvállalásában olyan tevékenységek áttekintése, gyakorlati példákon keresztül, amelyek a különleges bánásmódhoz kapcsolódhatnak. Ezen területek lehetnek a fogyatékosokkal, megváltozott munkaképességüekkel való bánásmód, illetve a tehetséghez, a tehetséggondozáshoz kapcsolódó tevékenységek. Jelen tanulmányban tovább szükitve a vizsgálódás területeit, olyan tevékenység csoportok kerülnek középpontba, amelyek a fogyatékosokkal, megváltozott munkaképességüekkel való különleges bánásmódhoz kapcsolódhatnak.

A vállalatok tevékenységeinek számbavételekor egy multinacionális gyógyszeripari nagyvállalat magyarországi leányvállalatának (vállalat1) CSR-je jelentette a bázis adathalmazt. A vállalat1 és a további 4 vállalat (vállalat2; vállalat3; vállalat4) CSR tevékenységének értékelése honlapjaik tartalomelemzésével történt. Az információk aktualitásának sokszinüsége miatt a honlapokon hozzáférhetö 2015-ös hírfolyamok és az azokhoz kapcsolódó sajtóközlemények külön elemzés tárgyát képezték.

A vállalatok honlapjainak és Fenntarthatósági jelentéseiknek tartalomelemzése, kiegészítve az aktuális vállalati híranyaggal, lehetöséget nyújtott egy széles spektrumú tevékenységleltár elkészí-téséhez a vállalati társadalmi felelösségvállalás fogyatékosokkal és megváltozott munkaképességüek-kel kapcsolatos területein.
\end{abstract}

Kulcsszavak: CSR, vállalatok társadalmi felelősségvállalása, fogyatékos, támogatás

Diszciplinák: közgazdaságtan, pszichológia 


\section{Abstract}

\section{SPECIAL TREATMENT OF THE CSR}

According to a broader definition offered by Kotler and Lee (2007, 10 p), the focus of corporate social responsibility (CSR) is on ,selecting an initiative that will do the most good for the social issue as well as the corporation". Following this line of reasoning, the purpose of this study is to examine through the use of practical examples those activities of CSR that can be in connection with the category of special treatment. To be more specific, these are the CSR activities related to the treatment of persons with a physical or mental disability and the treatment of people with reduced capacity to work.

When it came to reviewing the activities of the selected companies, the CSR activity of Hungarian Affiliate of a global pharmeceutical company (companyl) was considered as base. The CSR activities of the four other companies and the companyl were evaluated by performing a content analysis of their websites. Due to the divers sources of information, the news of 2015 and the press releases available on their websites were analysed separately.

The content analysis of the Sustainability reports and websites of the selected companies, supplemented with the latest company news, has opened the door to the preparation of a wide-spectrum activity inventory on the CSR areas related to the treatment of persons with a physical or mental disability and the treatment of people with reduced capacity to work.

Keywords: CSR, corporate social responsibility, disability, donation

Disciplines: economy, psychology

A címválasztásban dimenzióátalakítás és megszemélyesítés is megjelenik. Olyan dimenzióátalakítás, amit a társadalmi célú reklámok kutatói kreativitássablonként írnak le (Balázs, Barkó és Vancza, 2012). Ez részben arra utal, hogy a vállalati társadalmi felelösségvállalás (CSR, Corporate Social Responsivility) filozófiájának legfontosabb tartalma maga a társadalmi hasznosság, ugyanakkor egy piaci szereplőnek ki kell lépni abból a keretből, ahol Friedman szerint az etikai elveinket, megfontolásainkat kívül kell hagynunk, annak érdekében, hogy a pénz szabadon áramolhasson a kereslet-kínálat törvényeinek megfelelöen (Friedman, 1970), és erőforrásait részben a köz javára kellene fordítani. A fogalom (CSR) emberi tulajdonsággal (különleges bánásmód) felruházva, mint megszemélyesítés azt hangsúlyozza, hogy egy tartalmában és feltételeiben folyamatosan változó fogalomról van szó, amelynek alakítása humán kompetenciákat követel meg.

Kotler is beszámol arról, hogy az USA 500 legnagyobb vállalatának honlapját monitorozva a CSR (Corporate Social Resposibility) milyen sokféleképpen jelenik meg: vállalati felelösség (CR, Corporate Responsibility), globális állampolgárság, társadalmi célú marketing, vállalati civilség, vállalati filantrópia, vállalati részvétel a helyi közösség életében (Kotler és Lee, 2007).

A vizsgálatban résztvevő vállalatok honlapjain társadalmi szerepvállalás, társadalmi felelősségvállalás, fenntartható fejlődés, fenntarthatóság, felelősségvállalás, vállalati felelősségvállalás, vállalati társadalmi felelősségvállalás vagy CSR kifejezések fordulnak elő.

Jelen tanulmány a vállalati társadalmi felelősségvállalás (CSR) kifejezést használja.

A CSR történetével, tartalmával és a vállalati müködés hagyományos területeivel való összefüggéseivel számos szerző foglalkozik. Jelen tanulmány Kotler és Lee $(2005 ; 2007)$ gyakorlatorientált megközelítését veszi alapul. A CSR tárgyalásakor megkerülhetetlen a TBL (triple bottom line), a vállalatok társadalmi felelősségvállalását a fenntarthatóság három 
alappillérével összekapcsoló koncepció (Elkington, 1997). Kiegészítve az etikai megközelítés szempontjaival (Paine, 2000) ez vezet el a CSR nagyvállalatok által értelmezett gyakorlatához és annak kommunikációjához, ami összhangban van az EU hosszú távú céljaival is (European Commission, 2001; Net1).

A fogyatékosokkal és megváltozott munkaképességüekkel kapcsolatos legkézenfekvőbb tevékenység a munkavállalóként való alkalmazás. Az alkalmazásnak azonban számos akadálya lehet, ugyanakkor előnyökkel járhat gazdasági és egyéb szempontokból is. Ezen tanulmányban brit kutatási eredmények (Roberts és tsai, 2004) mellett, elsősorban a magyar kutatási tapasztalatok áttekintésére kerül sor. A témának széleskörü a hazai szakirodalmi megalapozottsága (Fedor, Münnich és Sipos, 2007; Dajnoki, 2012; Tardos, 2015; Kozák, 2015; Net2). A legfrissebb hazai kutatási eredményeket Tardos (2015) írja le.

A CSR területek fókuszált vizsgálatára a fogyatékosokkal, megváltozott munkaképességüekkel kapcsolatos tevékenységeket számba véve, nem található szakirodalmi forrás.

Jelen tanulmány újszerüségét az adja, hogy ezen CSR területeket a gazdálkodó szervezetek szemszögéből vizsgálja a lehetséges motivációik, a ténylegesen megvalósuló és közzétett gyakorlatuk áttekintésével. Beteljesíti a kutatás célkitüzését egy CSR tevékenységhálózat kialakításával, amely a fogyatékosokkal és megváltozott munkaképességüekkel kapcsolatos vállalati társadalmi felelös-ségvállalási területeket írja le a vizsgált vállalatok tekintetében.

A tanulmány első alfejezete a CSR egy haladó koncepcióját járja körül, magyarázatot keresve a vállalatok motivációira. Ezt követően kerül sor a fogyatékosokkal és megváltozott munkaképességüekkel kapcsolatos bánásmód vállalati szempontjainak számba vételére. Elsősorban alkalmazásuk lehetőségei, illetve annak lehetséges motivációi kerülnek kifejtésre. Majd az kerül áttekintésre, hogy milyen más lehetőségei lehetnek egy szervezetnek, ha szeretné kinyilvánítani elkötelezettségét a fogyatékosokkal, megváltozott munkaképességüekkel való törődés terén. Végül bemutatásra kerül vizsgálatunk és annak eredményei.

\section{A vállalati társadalmi felelősségvállalás (CSR)}

Philip Kotler definíciója szerint a vállalati társadalmi felelősségvállalás azt az elkötelezettséget jelenti, amely során a vállalat a közösség jólétének érdekében folytat önkéntesen, szabadon választott üzleti gyakorlatot, amit erőforrásaival is támogat (Kotler és Lee, 2005).

A fogalmat a másik irányból tekintve a Business for Social Responsibility szervezet szerint a CSR ,a vállalat oly módon való müködtetése, amely megfelel a vállalatokkal szemben a társadalom által támasztott etikai, jogi, üzleti és társadalmi elvárásoknak vagy túlteljesíti azokat" (Perrini, 2006, 307. o.).

Az etikai dimenzió bevonásával az önzetlen segítség mint a boldogság azon forrása, amellyel az egyén másokat, a közösséget szolgáló tevékenységét serkenti és jutalmazza (Végh, 2015) és a dolgozók motiválása a cég CSR-jéböl fakadó büszkeség fokozásával áll a széles spektrum egyik végén. A másik végén a Sas (2010) által Corporate Social Ravaszkodásnak aposztrofált viselkedés foglal helyet, amire egy szemléletes példa az egyik gyógyszergyártó nagyvállalat egykori kommunikációs igazgatójának nyilatkozata. Szerinte már önmagában az, hogy egy cég gyógyszert, az egészség visszanyerését, megőrzését biztosító terméket felelős módon állít elő, tekinthető egyfajta felelősségvállalásnak (Beke, 2009). Profitot termel, de „felelős módon”.

A vállalati társadalmi felelősségvállalás motivációit vizsgálva Paine és munkatársai azt találták, hogy ha a CSR szempontjából fontos döntéshozókat, zömében vállalatvezetőket kérdeznek meg a felelősségvállalás okairól, akkor legtöbbször az üzleti elönyökre hivatkoznak, ritkábban személyes elkötelezettségükre, még ritkábban pedig az erkölcsi kötelességre (Paine, 2000). 
Összefoglalva a CSR mellett szóló érveket:

- Az érintettekkel való kapcsolat menedzsmentjének eszköze lehet;

- Olyan eszköz, amit a versenytársak már használnak;

- Fejleszti a proaktivitást;

- Innovációra ad alkalmat (pl. környezettudatos fejlesztések);

- Segítségével a vállalat könnyebben juthat forrásokhoz, hiszen a vonzóbb lehet a befektetők számára;

- Fokozhatja a vállalat jó hírét.

A vállalatok a társadalmi felelősségvállalásukról gyakran Fenntarthatósági jelentés közzétételével számolnak be. Ennek terminológiája átvezet a CSR és a fenntarthatóság kapcsolatának feltárásához. A fenntartható fejlődés gyakorlati, mikroszintű megvalósításának eszköze a fenntarthatóság klasszikus három pillére (triple bottom line, TBL) a gazdasági, társadalmi és környezeti fenntarthatóság (Elkington, 1997). Lényege, hogy a vállalatnak nem csak a pénzügyi, de a fenntartható fejlődés mindhárom dimenziójában mérnie, értékelnie és fejlesztenie kell teljesítményét, sőt nyilvánosságra is kell hoznia azt. Ezzel a CSR a hosszú távú értékteremtés, a fenntarthatóság, mint makrocél mikro eszközévé válhat, amely összhangban van az Európai Bizottság állásfoglalásával, mely szerint a vállalatok társadalmi felelösségvállalásában az önkéntesség mellett a szociális és környezeti szempontok érvényesítésének is szerepelnie kell. Ezen túl a CSR a magánszektor fontos eszköze abban, hogy a vállalkozások aktívan részt vegyenek a fenntartható fejlődés elősegítésében, amely az EU hosszú távú célja a 2001-es „Zöld könyv” szerint (Net1).

A gazdálkodó szervezetek minden olyan önként vállalt tevékenysége, ami nem a közvetlen profitszerzést szolgálja, vagy nem a törvényi kötelezettségek teljesítésére irányul, hanem például túlteljesíti azokat (környezetvédelmi beruházások), CSR tevékenységnek tekinthető. Ezen tevékenységek célcsoportja lehet a szervezeten belül (munkavállalók), és a szervezeten kívül (szükebb környezet, tágabb környezet), vagy történhet egy általános társadalmi „közjó”(emberiség, a Föld) érdekében.

Jelen tanulmány a CSR területek szükebb keresztmetszetére fókuszál, ami a fogyatékosokkal, megváltozott munkaképességüekkel való bánásmóddal kapcsolatos tevékenységeket öleli fel. A következőkben csak a kifejezetten ezen területekhez kapcsolódó szempontok, motivációk és tevékenységek kerülnek áttekintésre.

\section{Fogyatékosok, megváltozott munkaképességúek}

Megváltozott munkaképességü személynek az tekinthető, aki testi vagy szellemi fogyatékos, vagy akinek az orvosi rehabilitációt követően munkavállalási és munkahely-megtartási esélyei testi vagy szellemi károsodása miatt csökkennek (Szabó, Kozicz és Ottrok, 2012).

A fogyatékos embereket az 1998 évi XXVI. törvény a társadalom egyenlő méltóságú, egyenrangú tagjaiként határozza meg, akik a mindenkit megillető jogokkal és lehetőségekkel csak jelentős nehézségek árán vagy egyáltalán nem képesek élni. A törvény fogalommagyarázatában a fogyatékos személy: az a személy, aki tartósan vagy véglegesen olyan érzékszervi, kommunikációs, fizikai, értelmi, pszichoszociális károsodással - illetve ezek bármilyen halmozódásával - él, amely a környezeti, társadalmi és egyéb jelentős akadályokkal kölcsönhatásban a hatékony és másokkal egyenlö társadalmi részvételt korlátozza vagy gátolja (1998. évi XXVI. tv.4. § a)).

A Munka Méltósága címü munkajogi projekt keretében a fogyatékossággal élők foglalkoztatási helyzetét is vizsgálták. A vizsgálat eredményeit ombudsmani jelentésben közölték 2012ben. Ebben rámutatnak, hogy a hazai jogrendszerben nem létezik egységes definíció a fogyatékos személy meghatározására. A fogalmak sokfélesége az egyes jog és szakterületek 
különbözőségéböl fakadhat. Ugyanakkor a megváltozott munkaképességü személy fogalomkör tág, és több homogén csoportot foglal magában, az egyes csoportokon belül is jelentős eltérések lehetnek az egészségkárosodás, illetve a fogyatékosság mértékét illetően. A vizsgálatban résztvevő szervezetekkel folytatott párbeszéd során, konszenzus mutatkozott abban, hogy a fogyatékkal élő személyek szóhasználat kerülendő (Szabó, Kozicz és Ottrok, 2012). A fogyatékos; fogyatékossággal élő; fogyatékos személy kifejezéseket a szakirodalom gyakran szinonim fogalmakként kezeli (Tardos, 2015).

Jelen tanulmány a megváltozott munkaképességü és fogyatékos kifejezéseket használja. Ugyan a megváltozott munkaképességüek köre tágabb, azonban ez a gyüjtőfogalom a vállalati CSR szempontjából kizárólag a foglalkoztatással kapcsolatban számottevő. A további tevékenységek célcsoportja egyértelmüen a fogyatékos személyek és a hozzájuk kapcsolódó intézmények, programok köre.

Tardos (2015) vizsgálataiban a munkaerö-piaci integrációt elősegítő tényezők közül az állami szabályozást (amely meghatározza azt a keretet, amelyben a szervezetek munkaerőgazdálkodási döntéseiket meghozzák), a munkáltató szervezeti kultúráját (ami a mögöttes értékrend révén befolyásolja a munkahelyi döntéshozók humán erőforrással kapcsolatos döntéseit), a szervezeti légkört (amelybe az új munkavállaló érkezhet), az atipikus munkaformák elterjedtségét (amely több hátrányos helyzetü csoport számára segítheti az elhelyezkedést) és a munkahelyi esélyegyenlőségi politikák és gyakorlatok színvonalát tartja meghatározónak. Ez utóbbi a vállalatok társadalmi felelősségvállalásának azon területe, amelybe a fogyatékosok és megváltozott munkaképességüek foglalkoztatása illeszthető.

A területre közvetlenül is befolyással bír, a vállalatok gazdálkodását érintő olyan törvényi kötelezettség, amely szabályozása az utóbbi években folyamatosan változott. Ez a kötelezettség a rehabilitációs járulék, amely hatással van a vállalatok gazdasági motivációjára a különböző tényezők és a várható költségek mérlegelésekor. A megváltozott munkaképességü személyek ellátásairól és egyes törvények módosításáról szóló 2011. évi CXCI. törvény (Mmtv.) 23. § (1) bekezdése szerint a munkaadó a megváltozott munkaképességü személyek (ide tartoznak a fogyatékossági támogatásban részesülők is) foglalkozási rehabilitációjának elősegítése érdekében rehabilitációs hozzájárulás fizetésére köteles, ha az általa foglalkoztatottak átlagos statisztikai állományi létszáma a 25 föt meghaladja, és az általa foglalkoztatott megváltozott munkaképességü személyek átlagos statisztikai állományi létszáma nem éri el a létszám 5\%-át. 2015. július 19-től főszabály szerint munkaerőkölcsönzés esetén a kölcsönzött munkavállalót a kikölcsönzés tartama alatt a kölcsönvevőnél kell a rehabilitációs hozzájárulás alapjául szolgáló statisztikai létszám számítása során figyelembe venni. Tekintettel arra, hogy az egyre rugalmasabb megoldásokat követelö munkaerőpiacon a munkaerő-kölcsönzés is jelentős szerepet játszik, ez a jogszabályváltozás lehetőséget biztosít a megváltozott munkaképességü munkavállalók foglalkoztatási spektrumának szélesítésére (Kovács, 2015).

Az Emberi Erőforrások Minisztériuma 2015-ben is meghirdette pályázatát megváltozott munkaképességü munkavállalók 2016. évi rehabilitációs célú tartós, vagy tranzit foglalkoztatásának támogatására (bérköltség és a megváltozott munkaképességéből fakadó többletköltségei). A pályázat célja a megváltozott munkaképességü munkavállalók foglalkoztatásának elősegítése, képzettsé-güknek és az egészségi állapotuknak megfelelő munkavégzés feltételeinek biztosítása, adaptációs készségük fejlesztése, az állapotukból adódó hátrányok kiegyenlítése tartós foglalkoztatás keretében, valamint a nyílt munkaerőpiacra való visszavezetése tranzit foglalkoztatás révén. Ennek elérése érdekében a cél olyan foglalkoztatók és munkahelyek kiválasztása és támogatása, amelyek a foglalkozási rehabilitáció megvalósításának feltételeit biztosítják (Net3).

A fogyatékos személyek társadalmi integrációjával kapcsolatban azt tartják a legnagyobb problémának, hogy ők az egészséges emberek számára láthatatlanok. Az oktatást tekintve, a 
speciális oktatási és szociális intézményekben a hasonló hátrányokkal élők találkoznak egymással. A speciális iskolákból (védett környezetből) csak a diákok töredéke kerül be a „normál” szakképzésbe, felsőoktatásba. A munkaerőpiacon is hasonló a helyzet, nagyon kevés fogyatékos ember jut el oda, hogy jelentkezni tudjon egy munkahelyre (Dajnoki, 2012). Alkalmazásukkal kapcsolatban a terhelhetőségükkel, teljesítményükkel összefüggésben merülhetnek fel kérdések (milyen gyakran lesznek betegek, hogyan tudnak majd beilleszkedni). Fedor, Münnich és Sipos (2007, 26. o.) a beilleszkedéssel kapcsolatban arra a megállapításra jutnak, hogy „...a legtöbb egészséges társ szintén valamilyen testi vagy lelki problémával küzd, a legnagyobb különbség többnyire az, hogy a megküzdés tárgya mennyire komoly, illetve milyen területen korlátozza az embereket".

Új belépő esetén speciális képzések, érzékenyítő tréningek segíthetik a munkahelyi beillesztés folyamatát. Ideális esetben ilyen tréningen az új belépőkön túl azok a beosztottak és vezetök is részt vesznek, akik mindennapi munkakapcsolatban állnak majd a fogyatékos, vagy megváltozott munkaképességü dolgozóval (Kozák, 2015).

Tardos (2015) kutatásai azt támasztják alá, hogy nagy előrelépést hozhat egy cég befogadó kultúrájának kialakításában, ha a szervezet elhatározza, hogy esélyegyenlőségi és sokszínüségi tervet dolgoz ki. A megváltozott munkaképességüek foglalkoztatása szempontjából előremutató lehet, ha a szervezet az esélyegyenlőségi tervben külön célcsoportként jelöli meg a megváltozott munkaképességü emberek csoportját, és a tervben dokumentálhatóan megjelenik, hogy milyen konkrét célkitüzéseket, jó gyakorlatokat kíván megvalósítani a csoporttal kapcsolatban.

Fontos még leszögezni, hogy a befogadó és sokszínü szervezet kialakításához elengedhetetlenül fontos a felsővezetői elköteleződés a szervezeten belül. A munkahelyi esélyegyenlöség megvalósításához hatékony segítséget nyújthat az erre a témára szakosodott civil szervezetekkel kialakított szorosabb együttmüködés. Ilyen együttmüködés eredménye lehet a Fogyatékosság barát munkahely védjegy megpályázása.

A Fogyatékosság barát munkahely védjegyet 2010-ben vezették be brit mintára. Az elismerést azóta minden évben az Emberi Erőforrások Minisztériuma, az American Chamber of Commerce in Hungary, a Szövetség a Kiválóságért Közhasznú Egyesület és a bevezető Salva Vita Alapítvány adja át a pályázati feltételeket teljesítő munkáltatóknak. A Fogyatékosság barát munkahely logó, - mint védjegy használatát elnyerő munkáltatóknak az Európai Minőségmenedzsment Alapítvány (EFQM) Kiválóság Modellje alapján kidolgozott koncepciónak kell megfelelniük. A díjat azon szervezetek nyerhetik el, amelyek vállalják, hogy folyamatosan fejlesztik a fogyatékos munkavállalók toborzásával, foglalkoztatásával, megtartásával kapcsolatos gyakorlatukat. A nyertes pályázó az elismerés megszerzését követően két évig használhatja a Fogyatékosság-barát Munkahely logót (Net4).

A szakirodalmat áttanulmányozva azt lehet mondani, hogy a fogyatékos, megváltozott munkaképességü munkavállalók foglalkoztatásának az alábbi előnyei lehetnek:

- Sok olyan megváltozott munkaképességü személy van, akinek örömet, kihívást jelent a munka, ezért motiváltabbak, figyelmesebben, gondosabban, pontosabban végzik feladatukat (Fedor, Münnich és Sipos, 2007; Roberts és tsai, 2004; Dajnoki, 2012).

- Nagyon szeretnének bizonyítani, ami meglátszik a teljesítményükben, emellett általában pozitívak, lelkiismeretesek, minőségcentrikusak, motiváltak és hálásak (Fedor, Münnich és Sipos, 2007; Dajnoki, 2012; Net2).

- Alacsony a fluktuáció, ritkán váltanak munkahelyet, ha képességeiknek, tudásuknak megfelelö munkatevékenységet végeznek, ezáltal a cég iránt elkötelezett, lojális munkaerőt jelenthetnek (Fedor, Münnich és Sipos, 2007; Dajnoki, 2012; Net2).

- A befogadásuk közösségépítő erőként javítja a munkamorált, erősíti a többi dolgozó szervezet iránti elkötelezettségét is, növeli az egymással szemben tanúsított toleranciát, tiszteletet. A nem megváltozott munkaképességü dolgozók nyitottabbá válnak 
a megváltozott munkaképességü kollégák felé és egymás felé is a közös munkavégzés során (Roberts és tsai 2004; Net2).

- A cég szervezettségét növelheti, hogy a megváltozott munkaképességü ember felvétele esetén, - a tervezés során, átvizsgálásra kerülnek a munkahelyi folyamatok, munkakörök, feladatkörök, lehetöséget teremtve az optimális feladatmegosztás és struktúra kialakítására (Net2).

- Propaganda értéke lehet a tervezetten, átgondoltan és megfelelöen kommunikált rehabilitációs foglalkoztatásnak (Roberts és tsai 2004; Dajnoki, 2012; Net2).

- Gazdasági érdekek kapcsolódhatnak hozzá, a rehabilitációs hozzájárulás kiváltásán túl igénybe lehet venni különböző támogatásokat, pályázatoknál is elönyt jelenthet (Roberts és tsai 2004; Fedor, Münnich és Sipos, 2007; Dajnoki, 2012; Net2).

- Bizonyos célcsoportok könnyen toborozhatóak az állami vagy civil szervek segítségével (Net2).

A szakirodalmi források körül járják a fogyatékosok és megváltozott munkaképességüek alkalmazásának korlátait és lehetőségeit. Az alkalmazáson kívül azonban más CSR tevékenységre vonatkozó részletes szakirodalmi okfejtés nem áll rendelkezésre. Ugyanakkor számot kell vetni egyéb kezdeményezésekkel is. Segítheti a befogadó vállalati kultúra kialakítását a különböző rendezvények szervezése, például „Fogyatékossággal élők vállalati napja", de a különböző munkavállalói csoportok vagy ügyfelek, partnerek, esetleg beszállítók számára szervezett képzések is hozzájárulhatnak a befogadó kultúra kialakításához (Tardos, 2015).

Az Emberi Erőforrások Minisztériuma 2010-ben indította el a Segítő Vásárlás programot, annak érdekében, hogy felhívja a közvélemény figyelmét a fogyatékossággal élő emberek közremüködésével készített termékekre és szolgáltatásokra. A programhoz védjegyet jegyeztettek be 2013-ban. A védjegyet a megváltozott munkaképességű embereket foglalkoztató akkreditált, védett munkáltatók használhatják termékeiken, tanúsítva, hogy ezek a termékek megváltozott munkaképességüek közremüködésével készültek. Ennek keretében 2014. júniusától egy design projekt is elindult azzal a célkitüzéssel, hogy a kortárs ízlésnek megfelelö, piacképes termékek készüljenek a fogyatékossággal élöket foglalkoztató mühelyekben formatervezőkkel együttmüködve.

Vállalati oldalról megközelítve a témát segítő vásárlásról akkor beszélünk, ha megváltozott munkaképességü emberek által készített terméket értékesítenek. Ez történhet szervezett formában a vállalatok telephelyein, más érzékenyítő programokkal összekötve.

Nem csak termékek, hanem szolgáltatások is beszerezhetők olyan vállalkozásoktól például hoteltől, étteremtől vagy digitális reklámügynökségtől -, amelyek fontos jellemzője, hogy munkavállalóik zöme megváltozott munkaképességü, vagy fogyatékos. Ekkor megvalósul a fogyatékosok és megváltozott munkaképességüek foglalkoztatása is, így mind a keresleti mind a kínálati oldalon részben CSR tevékenységek állnak.

Jelen tanulmány az alkalmazással és az alkalmazáson túl megvalósítható, fogyatékosokkal és megváltozott munkaképességüekkel összefüggő CSR tevékenységek körének rendszerezésére vállalkozik a vizsgálatban szereplö vállalatok gyakorlatát értékelve.

\section{A vizsgálat célja}

Az alábbiakban öt nagyvállalat CSR tevékenységére irányuló vizsgálat bemutatására kerül sor. A vizsgálat célja az volt, hogy minél szélesebb körben tárjam fel a vállalatok társadalmi felelősségvállalásának azon területeit, amelyek a fogyatékosokkal, megváltozott munkaképességüekkel való bánásmódhoz köthetők. Ugyanakkor nem cél a vizsgálatban szereplő vállalatok CSR tevékenységének maradéktalan leírása, mivel ez kizárólag honlapjaik elemzésével nem is valósítható meg. 


\section{Minta}

A vizsgálatban szereplő vállalatok körének meghatározásához egy a Szerző vezetésével a Debreceni Egyetemen zajló kérdőíves kutatás ( $n=321$ fö) részeredményei kerültek felhasználásra. A kutatás a vállalatok társadalmi felelősségvállalásának összefüggéseit vizsgálja hallgatói munkahely választási preferenciákkal egyetemi hallgatók körében. A kérdőívben olyan vállalatokról kérdeztük a kitöltőket, amelyek különböző iparágakat képviselnek, vagy CSR-rel kapcsolatos média megjele-nések (kereskedelmi televíziós reklámok, elektronikus és nyomtatott sajtó) köthetők hozzájuk. A kérdőívek kiértékelése során akkor kerülhetett be egy vállalat jelen kutatás mintájába, ha CSR tevékenységével kapcsolatban érkezett válaszadás. Ez lehetett szöveges formában a szabad asszociá-ciós kérdésben, illetve szerepelhetett a vállalat a jó vagy rossz CSR gyakorlatáról ismert vállalatokat firtató nyílt kifejtendő kérdésre adott válaszokban.

A vizsgálat célkitüzéseinek megfelelően a vállalatok $(n=5)$ kiválasztásának egyik szempontja volt, hogy különböző iparágak képviselői legyenek. A vizsgálatban résztvevő vállalatok ${ }^{1}$ :

- A vállalat1 Magyarország egyik vezető gyógyszeripari vállalata. Dolgozói létszáma eléri a 2000 föt. Budapesten, és további 3 vidéki városban vannak gyártó és logisztikai telephelyei. 2010-ben a máig tartó „Transforming” vállalatcsoport szintű átalakítási projekt előhírnökeként a korábbi „Az egészség a legfontosabb” küldetés helyébe belépett a prevenciót hangsúlyozó „Gyógyszergyárból egészséggyár”.

- A vállalat2 Magyarország egyik legnagyobb külföldi ipari munkaadója 9 telephellyel és 10500 fős dolgozói állománnyal. Vállalati társadalmi felelösségvállalási filozófiájának kulcs üzenete: a felelősség bizalmat teremt. A vállalatalapító szellemi örökségére füzik fel tevékenységüket. A vevői elégedettség és bizalom, az oktatás támogatása vállalati keretek között és azon kívül, a dolgozók megbecsülése, erősítve ezzel lojalitásukat és a környezettudatos gazdálkodás állnak tevékenységeik középpontjában.

- A vállalat3 szolgáltató központjai rendszerintegrációs és üzemeltetési területeken szolgálják ki nemzetközi ügyfeleiket. A vállalat székhelye Budapesten van, további négy telephelye pedig vidéki nagyvárosokban található. Munkavállalói létszáma 4000 fö. Számukra a vállalati társadalmi felelősségvállalás egy olyan szemléletmódot, vállalatirányítási politikát jelent, amely a vállalat müködésébe beépíti a felelős társadalmi és környezetvédelmi célkitüzéseket a fenntartható fejlődés jegyében.

- A vállalat4 a vállalati piac egyik vezető bankjaként definiálja magát. Több mint 60 bankfiókban, telefonon és interneten szolgálja ki ügyfeleit. A Banknál reorganizációs program zajlik 2014. decembere óta, aminek célja a hatékonyság növelése, ez részben tulajdonosváltáshoz kapcsolódik, de legfőbb oka a bank korábbi gazdaságtalan működése. A létszámleépítések során a dolgozói létszám 1700 fő alá zsugorodott. A vállalat4 Etikai kódexében külön területként jelennek meg az alapelvek: társadalmi felelősségvállalás; fenntarthatóság és etika; személyiségi jogok és a diszkrimináció elleni védelem; felelősségvállalás témakörökben. Hangsúlyozzák, hogy elkötelezett támogatói a szociális, a tudományos, a kulturális-múvészeti és a sport- szférának.

- A vállalat5 1995 óta müködik Magyarországon. 209 boltot üzemeltet, amellyel az ország legnagyobb hipermarket kereskedelmi láncát építette ki. Több mint 20 ezer munkavállalónak biztosít állást, akik közül 1000 fő́t megközelít a megváltozott munkaképességü dolgozók létszáma. A vállalat felelősségvállalási stratégiája azon

\footnotetext{
1 Szerkesztőségi megjegyzés: tekintettel arra, hogy a Szerző nem tudott írásbeli hozzájárulási nyilatkozatokat bemutatni, melyben az elemzésre kerülő vállalatok felelős képviselői hozzájárulásukat adják jelen tanulmányban a vállalatok megnevezéséhez, s a tanulmány tartalma kéretlen pozitív/negatív hatással lehet az egyes vállalatok megítélésére, szerkesztőségi kérésre a vállalatok megnevezésére nem kerül sor - ugyanakkor igazoljuk, hogy a Szerző a Szerkesztőség számára bemutatta az itt tárgyalt honlapok URL címeit, s a vállalatok neveit.
} 
alapul, hogy szakértelmét és lehetőségeit arra használja, hogy a közösségek számára legfontosabb ügyeket kezelje, és a társadalom egésze számára hozzon létre értéket. Kiemelt figyelmet fordít három fő területre: az egészséges életmód népszerüsítésére, az élelmiszer-hulladék csökkentésére, valamint a fiatalok fejlődési lehetőségeinek bövítésére.

A résztvevő vállalatok mindegyike 500 főnél több munkavállalót foglalkoztató szervezet. Különböző iparágakat képviselnek, CSR tevékenységük számottevő. Regionális szempontból a dunántúli régiók kissé alulreprezentáltak. A minta nem reprezentatív, a vizsgálati eredmények a vizsgálatban szereplő vállalatok tekintetében értelmezhetőek. Ezen tényezők ellenére a vizsgálat megbízható forrásként szolgálhat a magyarországi nagyvállalatok fogyatékosokkal és megváltozott munkaképességüekkel kapcsolatos CSR tevékenységek feltérképezésére.

\section{Módszer}

A tartalomelemzés egy olyan módszer, amellyel információgyüjtést és elemzéseket lehet végezni különböző forrásokból. Az elemzési egységek, szavak, szókapcsolatok, más jellegü tartalmi összefüggések (mögöttes tartalom, következtetés) egyaránt lehetnek. A tartalomelemzés lényege, hogy az adatgyüjtés során valamilyen társadalmi produktumot, akár honlapot, jelentést „kérdezünk” az empirikus adatok forrásaként. Kvalitatív és kvantitatív módszerek együttes használatára is lehetőséget ad.

Jelen kutatásban a tartalomelemzés során a Lehota (2001), által megfogalmazott munkafázisok képezték a vezérfonal kvalitatív ágát. Szerinte a modern tartalomelemzések kvalitatív jellegüek, amelyekben a kategóriarendszer a vizsgálat folyamán is bővülhet. Az alábbi munkafázisokat javasolja:

- Az első fázis a kódolás szakasza, amelyben a kódolás nem elöre meghatározott kategóriák szerint történik, hanem ezek az elemzés folyamatában alakulnak ki.

- A második fázis az elemzés, amelyben az előfordulási gyakoriságot, az együttes előfordulást célszerü vizsgálni.

- A harmadik fázis az értelmezés, amely során a tendenciaszerü együttes előfordulások alapján a szövegbeli törvényszerüségekre lehet következtetni.

Az ilyen kvalitatív tartalomelemzés az elemzési egységek többszöri átolvasását jelentheti, amelyben az első olvasásban a kutató ,engedi magára hatni” az adott szöveget, hogy megfelelő kategóriákat alakíthasson ki. A vizsgálat részét képezik az előre meghatározott, és a vizsgálat során kibontakozó kategóriák. Ezzel a módszerrel a rejtett, nem tudatos, lappangó jelentések, igények és motivációk is jól kutathatók.

Majoros (2004) értelmezésében a tartalomelemzés során a kutatónak a szóbeli vagy írásbeli szöveget kvantifikálhatóvá, mérhetővé, elemezhetővé kell, alakítania Ehhez szerinte is többször végig kell olvasni az anyagot, és ki kell gyüjteni a speciális állításokat, témákat, s ezeket vizsgálati kategóriákká kell alakítani. Ezt követően az újbóli olvasás során számolni, ill. kódolni kell a kategória előfordulását, és gyakoriságot kell képezni. Ezt már lehet elemezni.

A vállalat1 tekintetében a tartalomelemzésbe bevont honlapok a magyarországi vállalati honlap, az onnan elérhető tematikus CSR honlap, a tematikus honlapról letölthető Fenntarthatósági jelentések (2008-2009; 2010-2012) valamint a Rövid jelentés (2008-2009).

A további vállalatoknál a vállalat 2 magyarországi vállalati honlapja, a vállalat 3 honlapja, a vállalat4 honlapja és a vállalat5 magyarországi honlapja, valamint a vállalatok legfrissebb közzétett Fenntarthatósági jelentései képezték a tartalomelemzés tárgyát. 
Miután a tartalomelemzésben számszerüsíthető mutatók segítségével is vizsgálhatók a sajtómegjelenések (Móré, 2008), valamint a honlapok CSR-hez kapcsolódó felületei nem minden esetben naprakészek, indokolt volt külön figyelmet fordítani a 2015-ös hírfolyam (1. táblázat) és a kapcso-lódó letölthető releváns sajtóközlemények elemzésére.

1. táblázat: vállalatok 2015-ös hírfolyamának összesített adatai (forrás: a Szerzö)

\begin{tabular}{lrrr}
\hline Vállalat & $\begin{array}{r}\text { Összes hír } \\
(\mathbf{d b})\end{array}$ & $\begin{array}{r}\text { CSR hír } \\
(\mathbf{d b})\end{array}$ & $\begin{array}{r}\text { CSR hír } \\
\text { arány } \\
(\%)\end{array}$ \\
\hline Vállalat1 & 9 & 1 & 11,1 \\
Vállalat2 & 70 & 17 & 24,3 \\
Vállalat3 & 35 & 23 & 65,7 \\
Vállalat4 & 28 & 2 & 7,1 \\
Vállalat5 & 41 & 20 & 48,8 \\
\hline
\end{tabular}

A vállalatokról honlapjaikon keresztül naprakész információt hírfolyamaik szolgáltatták. A vizsgált vállalatok az első táblázatban látható számban és összetételben tettek közzé híreket 2015-ben. A legtöbb hírt a vállalat2 honlapján tették közzé 2015-ben, míg a legtöbb CSR tevékenységgel összefüggő hír az vállalat3 honlapján jelent meg, ami az összes 2015-ben közzétett hírük közel $66 \%$-a. A vállalat1 és a vállalat4 egy nagyságrenddel kevesebb CSR hírt tett közzé.

A vállalat1 honlapján Fenntartható fejlődés navigációs ablakon keresztuil jutunk el a vállalat felelősségvállalási honlapjára.

A vállalat2 honlapon a vállalat2 csoport Magyarországon oldalon Fenntarthatóság és Innováció menüpontban található a CSR tevékenységük leírása. A részletes információk angol nyelven hozzáférhetőek. Magyar nyelvü hírek és sajtóközlemények számolnak be az aktualitásokról.

A vállalat3 honlapján a Bemutatkozás menüben szerepel Társadalmi felelösségvállalásuk. Számot adnak jó gyakorlataikról a Környezetvédelem és a Társadalmi szerepvállalás területén. Külön menüpontban helyezték el Tudásba fektetünk szlogennel a CSR-jük oktatással, képzéssel, tehetséggel kapcsolatos elemeit.

A vállalat4 honlapon Társadalmi szerepvállalás menüpontban található a bank CSR tevékenységének gyüjteménye. Legfrissebb letölthető jelentés a 2011-es Fenntarthatósági jelentés magyar és angol nyelven.

A vállalat5 honlapján Vállalat5 és közösségek menüpontban érhető el a CSR tevékenység, illetve a kezdő oldalon találjuk a hírfolyamot. Legfrissebb letölthető jelentésük 2012/2013 évi.

Miután a honlapokon a CSR tevékenység nem jelent meg egységesen, indokolt volt a tartalomelemzés kiterjesztése a vállalatok honlapjainak teljes terjedelmére. A kutatás másik pillérét a 2015-ös hírfolyam elemzése jelentette, mert ez bizonyult az aktuális CSR tevékenységek leghitelesebb forrásának. Ezt követően került sor a honlapokról letölthetô jelentések pdf formátumban való tartalomelemzésére.

$\mathrm{Az}$ adatelemzésekhez felhasznált szoftver a Microsoft Excel 2013 volt, míg az ábra készítéséhez a Microsoft Office 2013 SmartArt alkalmazására került sor. 


\section{Eredmények}

A honlapok és hírfolyamok tartalomelemzése alapján összeállítható egy széles spektrumú CSR tevékenység rendszer. Az 1. ábra összefoglalja a vállalati társadalmi felelösségvállalás azon tevékenységeit, amelyek a fogyatékosokkal és a megváltozott munkaképességüekkel való bánásmódhoz köthetőek.

1. ábra: CSR tevékenységek fogyatékosokkal, megváltozott munkaképességüekkel kapcsolatban (forrás: a Szerzö)

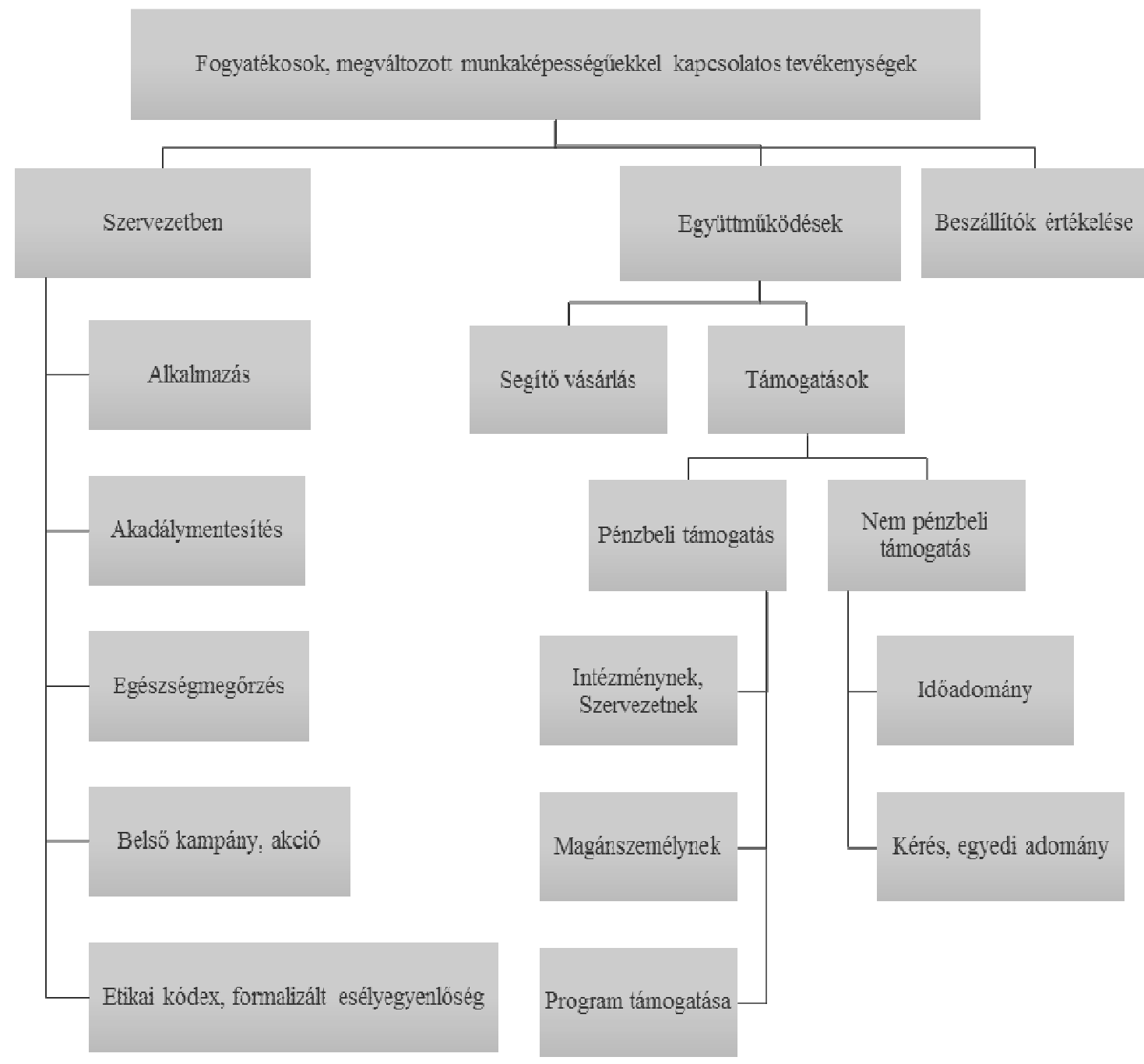

A továbbiakban gyakorlati példákon keresztül kerülnek bemutatásra azok a CSR tevékenységek, amelyek a fogyatékosokkal és megváltozott munkaképességüekkel való bánásmóddal hozhatók összefüggésbe.

Alkalmazás: A vállalat5 2015-ben harmadik alkalommal vehette át a Fogyatékosság-barát Munkahely címet, amely elismeri a vállalat fogyatékos emberek iránti elkötelezettségét. Az áruházlánc évek óta megfelel a törvényi kötelezettségnek és 5 százalék feletti létszámban 
alkalmaz megváltozott munkaképességü kollégákat. Ez jelenleg 960 föt jelent, akik jellemzően árellenőr, árufeltöltő és pénztáros munkaköröket töltenek be a vállalatnál.

Akadálymentesítés: Az akadálymentesítés történhet az épületek akadálymentesítésével, az ügyintézés, a terméktámogatás területén történő akadálymentesítéssel, vagy magát a terméket is „akadály-mentesíthetik”. Az utóbbira példa a vállalat1 Európai Unióban forgalmazásra kerülő termékeinek Braille írással történő feliratozása (ez 2005 óta Magyarországon kötelezö).

Egészségmegörzés: A vállalat1-nél minden saját állományú munkavállaló részére szürőnapot szerveznek egy, a telephelyük közelében lévő egészségcentrumba, munkaidő kedvezményt biztosítva.

Belsö kampány, akció: A vállalat1-nél müködik a MOZAIK Program, ami a fogyatékosok foglalkoztatási és támogatási programja. Ennek keretében az erre dedikált napon - ezt a Fogyatékos Emberek Nemzetközi Napjához igazítják, ami 1992 óta december 3-a - a fogyatékosokra irányítják a figyelmet. Minden telephelyre meghívnak fogyatékos müvészeket, sportolókat, akik előadják produkcióikat, beszámolnak mindennapjaikról. A meghívottakkal a továbbiakban is együttmüködések valósulhatnak meg, erre példa az az úszó paralimpikon, akinek felkészülését a vállalat1 egyik vidéki telephelye támogatta. Ennek az együttmüködésnek további jellemzője, hogy dolgozói kezdeményezésre jött létre.

Etikai kódex, formalizált esélyegyenlöség: Formalizált Etikai kódex minden a vizsgálatban résztvevő vállalatnál létezik. Személyiségi jogok és a diszkrimináció elleni védelem címen külön fejezetben szerepel a fogyatékosság hátrányos megkülönböztetésének tilalma a vállalat4 Etikai kódexében.

Segítő vásárlás: Együttmüködés keretében segítő vásárlás valósul meg, mikor a vállalat3 telep-helyein az egyik vidéki nagyvárosban és Budapesten évente több alkalommal szerveznek jótékonysági vásárt, ahol fogyatékos és megváltozott munkaképességü emberek által készített ajándéktárgyakat vásárolhatnak meg a dolgozók. A vállalat1 segítő vásárlással müködik együtt egy 95 százalékban fogyatékosokat alkalmazó hotellel, amikor tréningjeit a szállodában rendezi meg, kifejezetten a szálloda alkalmazotti struktúrája okán.

Pénzbeli támogatás intézménynek, szervezetnek: A vállalat2 2015 második félévében pénzado-mánnyal támogatott egy speciális nevelési igényü és sérült gyerekek oktatását végző intézményt. A vállalat5 és a Magyar Paralimpiai Bizottság közötti együttmüködés lényege, hogy a paralimpiai programok közvetlen támogatása mellett abban is közremüködnek, hogy a paralimpia szellemisége, a fogyatékossággal élő sportolók példaértékü teljesítménye minél szélesebb közönséget érjen el. 2012 nyarán áruházi adománygyüjtést szerveztek, és vásárlóik adományaival együtt pénzadománnyal támogatták a magyar csapat londoni paralimpiai szereplését. A paralimpiai mozgalom és a fogyatékos sport országos szintủ népszerüsítésére kiírt „London Paralimpia 2012” fotópályázat nyertes képeit egy országjáró kiállítás keretében 22 áruházukban mutatták be vásárlóiknak.

Pénzbeli támogatás magánszemélynek: A vállalat5 megalapította a „Mozgás Korlátok Nélkül" parasport ösztöndíjat, hogy a riói felkészülésben segítsék a tehetséges, de nehéz körülmények között élő sportolókat. A díjazottak körét a vállalat5 minden évben egy fővel bővítette az idei paralimpiáig.

Program támogatása: A Kézenfogva Alapítvány azzal a céllal jött létre, hogy javítani próbáljon az értelmi és halmozottan fogyatékos gyermekek és felnőttek életminőségén. A vállalat4 kiemelt támogatóként járult hozzá több alkalommal egy értelmi és halmozottan fogyatékos gyermekek és felnőttek életminőségét javítani próbáló civil szervezet családi napjának szervezéséhez. 2011-ben pedig egy civil szervezet vakvezető kutya kiképző programját támogatta.

Időadomány: A vállalat3 munkatársai önkéntes munkákat végeztek egy ifjúsági táborban, mely sajátos nevelési igényü tanulók, mozgásszervi, érzékszervi, értelmi és beszéd fogya- 
tékos, autizmus spektrumzavarral vagy egyéb pszichés fejlődés zavarral küzdő gyerekek, valamint nevelőik és szüleik számára nyújt táborozási lehetőséget. Egy civil szervezetnél pedig a rendszeres és elhúzódó kórházi kezelésben részesülő gyermekek számára építettek ki wifi hálózatot, hogy ezzel tegyék könnyebbé a gyermekek számára az otthonuktól távol töltendő időt.

Kérés, egyedi adomány: A vállalat2 egy civil szervezettel müködött együtt 2015-ben, s segítségükkel Budapesten egy kerületében óvodák és bölcsődék pedagógusai kaptak egy-egy laptopot. Ök olyan intézmények munkatársai voltak, amelyek az említett civil szervezet diabétesz oktató programjában vettek részt, és küzdöttek a diszkrimináció ellen, felkészülve arra, hogy cukorbeteg gyerekeket is ellássanak. Ezzel olyan egyedi adományokat adtak, amelyekre az igényeket felmérve volt szükség az intézményekben.

Beszállitók értékelése: Beszállítók értékelésére a fogyatékosokkal, megváltozott munkaképességüekkel való bánásmód alapján a vállalat4 etikai kódexében található elvi iránymutatás. Ebben lefektetik a tisztelettel és toleranciával jellemezhető munkahelyi légkör támogatásának alapelveit. Tiltást fogalmaznak meg bármely munkatárs bárminemü hátrányos megkülönböztetésére vagy zaklatására, kora, neme, vallása, világnézete, faja, illetve etnikai hovatartozása vagy szociális helyzete, fogyatékossága vagy szexuális identitása és irányultsága miatt. Jogi következmények érvényesítését helyezik kilátásba a nem megengedett magatartással szemben. Megfogalmazzák ezen elvárásaikat a szállítói és szolgáltatói üzleti partnereikkel szemben is.

\section{Konklúzió}

Jelen kutatás feltárta a vállalatok társadalmi felelősségvállalásának széles eszköztárát, rávilágít a benne rejlő potenciálra a fogyatékosokkal, megváltozott munkaképességúekkel való bánásmód területén a kapcsolódó tevékenységek és a jó gyakorlatok felvonultatásával.

A fogyatékos, megváltozott munkaképességü személyekkel, szervezeteikkel kapcsolatos CSR tevékenységek a vállalatoknál a legtöbb esetben szigetszerünek tűnnek. Érzékelhető, hogy a megválozott munkaképességúek foglalkoztatásának komoly korlátai vannak: nagyobb arányú foglalkoztatást valójában az a vállalat tud biztosítani, amely képes megfelelő számú alkalmas munkakört kínálni.

Az összeállított tevékenységleltár jól használható a vállalati gyakorlatban, meglévő gyakorlataik rendszerezésében, és új tevékenységek kialakításában.

\section{Korlátozások és lehetőségek}

Azon túl, hogy a CSR tevékenység „önkéntes, önbevallásos” jellege alapjaiban nem tekinthető objektív adatközlésnek, a tanulmány legfőbb korlátjának a minta megválasztása bizonyult. A vizsgált vállalatok tevékenységei között sok a hasonlóság, érdemes lehet a továbbiakban más iparágak képviselőit is bevonni a kutatásba. A másik kihívást az támasztotta, hogy a vizsgált honlapok nem voltak naprakészek a CSR tevékenységeket illetően. Nagyban segítette a munkát a 2015-ös hírfolyam részletes tartalomelemzése. Ennek ellenére még teljesebb képet kaphatunk, ha a vállalatok részéről kompetens adatközlöt tudunk bevonni a kutatásba.

Nem szabad megfeledkezni a tartalomelemzés módszerének hiányosságairól sem. Mindenekelőtt tudni kell, hogy az objektivitás a legsebezhetőbb pontja. Alkalmazása során erre külön figyelmet kellett fordítani. Ez azt jelenti, hogy a tartalomelemzés során nem kell sok kategóriát megállapítani, a megállapítottakat pontosan kell definiálni, és jelen esetben konzekvensen ragaszkodni a definíciókhoz minden vizsgált adatközlő (itt a honlapok, hírfolyamok, jelentések) esetében. 
További vizsgálati módszerek alkalmazása - például interjú vállalati CSR felelös szakemberrel - a témakörök teljesebb kidolgozására adhat lehetőséget. Célszerü lehet a vállalatok körének más módszerrel való kiválasztása. Olyan mintát választva folytatni a kutatást, hogy az eredmények iparági értékelésekre is lehetőséget adjanak.

\section{Irodalom}

1998. évi XXVI. törvény a fogyatékos személyek jogairól és esélyegyenlöségük biztosításáról

2003. évi XCII. törvény az adózás rendjéröl (Art.)

2011. évi. CXCI. törvény a megváltozott munkaképességü személyek ellátásairól és egyes törvények módosításáról (Mmtv.)

Balázs K., Barkó M. és Vancza, G. (2012). Társadalmi célú reklámok kreativitássablonjai és hatásmechanizmusuk Alkalmazott pszichológia 2012/1, 5-24.

Dajnoki K. (2009). Fogyatékos, illetve megváltozott munkaképességü személyek foglalkoztatásának munkaerő piaci megítélése. Gazdasági és társadalomtudományi közlemények 2012.IV/2., 251-260.

Elkington, J. (1997). Cannibals with Forks: the Triple Bottom Line of 21st Century Business. Oxford: Capstone Publishing Ltd.

EUROPEAN COMMISSION (2001). Green Paper: Promoting a European Framework for Corporate Social Responsibility. Letöltés: 2015.12.07. Web: file:///C:/torrent/DOC-019_EN.pdf

Fedor Gy., Münnich Á. és Sipos, S. (2007). A munkaadó szervezetek megváltozott munkaképességü munkavállalók foglalkoztatására való felkészültségének feltáró vizsgálata In Münnich Á. (szerk.): Gyakorlati megfontolások és kutatási tapasztalatok a megváltozott munkaképességü emberek foglalkoztatásához. Didakt Kiadó, Debrecen. 25-45.

Friedman, M. (1970). The social responsibility of business is to increase its profits, New York Times Magazine, szeptember 13. 211-214.

Kotler, P. és Lee, N. (2007). Vállalatok társadalmi felelösségvállalása. Budapest: HVG Kiadó Zrt.

Kotler, P. és Lee, N. (2005). Corporate Social Responsibility. Hoboken: John Wiley \& Sons, Inc.

Kovács Sz. (2015). Változott a rehabilitációs hozzájárulás számítása. Letöltés: 2015.11.01. Web: www.munkajog.hu

Kozák A. (2015). A beillesztési program tartalma és szabályozása. Munkaügyi Szemle 2015/6, 46-52.

Lehota J. (2001) Marketingkutatás az agrárgazdaságban. Mezőgazda Kiadó, Budapest.

Majoros P. (2004) A kutatásmódszertan alapjai. Perfekt, Budapest.

Móré M. (2008) A tartalomelemzés szerepe a vezetéstudományban In Dienesné-Pekurár (szerk.): Hagyományok és új kihívások a menedzsmentben. Debreceni Campus Nonprofit Közhasznú Kft., Debrecen. 430-435.

Net1: www.ec.europa.eu/growth/industry/corporate-social-responsibility/index_en.htm Letöltés: 2016.01.11.

Net2: www.frtt.hu Letöltés: 2016.01.07.

Net3: www.kormany.hu/hu/emberi-eroforrasok-miniszteriuma/szocialis-ugyekert-estarsadalmi-felzarkozasert-felelos-allamtitkarsag Letöltés: 2016.01.12.

Net4: www.salvavita.hu Letöltés: 2016.01.19.

Paine, L. S. (2000). Does Ethics Pay? Business Ethics Quarterly, X/1., 319-330. 
Perrini, F. (2006). SMEs and CSR Theory: Evidence and Implications from an Italian Perspective. Journal of Business Ethics 67., 305-316.

Roberts, S., Heaver, C., Hill, K., Rennison, J., Stafford, B., Howat, N., Kelly, G., Krishnan, S., Tapp, P., és Thomas, A. (2004). Disability in the workplace: Employers' and service providers' responses to the Disability Discrimination Act in 2003 and preparation for 2004 changes. Letöltés: 2016.01.07. Web: www.webarchive.nationalarchives.gov.uk/ 20130314010347/http:/research.dwp. gov.uk/asd/asd5/rports2003-2004/rrep202.pdf)

Sas I. (2010). Corporate Social Ravaszkodás! Mai Piac 2010/1

Szabó M., Kozicz Á. és Ottrok V. (2012). AJB - 2618/2012 Jelentés. Letöltés: 2016.02.29. Web: http://tamogatoweb.hu/ekonyvtar_pdf/fogyatekossaggal-elok-foglalkoztatasi-helyzete.pdf

Tardos K. (2015). Halmozódó diszkrimináció kirekesztés és integráció a munkaerőpiacon. Belvedere Meridionale, Szeged.

Végh L. (2015) Fenntartható élet. Letöltés: 2015.12.10. Web: http://w3.atomki.hu/kornyezet/ f15o.pdf

\section{Konferencia előadások}

Beke Zs. (2009) CSR a vállalati gyakorlatban - már tudjuk vagy még mindig csak tanuljuk? CSR Hungary Konferencia 2009. okt. 15. Budapest

Executive Summary, (2015) EU Multi Stakeholder Forum on Corporate Social Responsibility 3-4 February, 2015 Brussels

Fehér M. (2010) Munkahelyfeltáró program „Bőröndös” CSR Hungary Konferencia 2010 nov. 10-11. Budapest 